\title{
Relationship between Sentinel-2 orbital data and in situ monitoring of coffee rust
}

\author{
Matheus Luiz Jorge Cortez ${ }^{1}$ (1) $\cdot$ Marcelo de Carvalho Alves ${ }^{1} \cdot$ Gladyston Rodrigues Carvalho $^{2} \cdot$ Edson Ampélio Pozza $^{3}$
}

Received: 24 March 2020 / Accepted: 24 July 2020 / Published online: 31 July 2020

(c) Springer Nature Switzerland AG 2020

\begin{abstract}
Coffee rust (Hemileia vastatrix Berkeley \& Broome) is the main coffee disease in Brazil. Coffee rust control is calendarbased and performed by applying chemicals in order to avoid the outburst of disease epidemics. The aim of this work was to identify coffee rust using multispectral orbital sensing through analyses utilising vegetation indices and coffee rust incidence, defoliation and yield data obtained in situ. Field samples were georeferenced using a high-accuracy global navigation satellite system receiver in two plots, in a 42-year-old, leaf rust susceptible coffee cultivar. Conventional chemical control of rust was performed in only one of the plots to serve as control. Coffee rust incidence in areas with and without chemical control was assessed over 5 months, from December 2018 to April 2019, a period with optimal environmental conditions for disease occurrence. Following analyses of different vegetation indices and data sampled in the coffee crop, Pearson's correlations between the variables were verified. Reported correlations occurred mainly among coffee rust incidence levels in February 2019 and vegetation indices calculated using Sentinel-2 images from August 2018, September 2018 and February 2019 [IRECI $r=0.566$; IRECI $r=0.493 ;$ NDMI $r=-0.518$; NDVI(RE1) $r=-0.562$; $\mathrm{Cl}(\mathrm{RE} 1) \mathrm{r}=-0.573$; MSR(RE1) $r=-0.569$ ], in areas without coffee rust control. Indices based on relationships between bands in the Red-Edge and Near Infra-Red regions were more sensitive to spectral changes in vegetation due to variation in coffee rust occurrence over time.
\end{abstract}

Keywords Remote sensing · Vegetation indices · Precision agriculture · Sentinel-2

\section{Introduction}

The coffee plant (Coffea arabica L.) is of great economic, social and cultural relevance in Brazil and around the world. Effective management of coffee crops can ensure good productivity, generating greater economic return, and reducing detrimental impacts to the environment.

The disease known colloquially as coffee leaf rust poses a significant threat to Brazilian coffee producers, due to favourable environmental conditions in most coffee regions of the country, and where there is still widespread use of susceptible varieties [39]. The pathogenic fungus can cause losses of up to $50 \%$ if no control measures are employed $[34,49]$.

Control measures for coffee rust are administered across entire plantations, carried out with the use of protective and systemic fungicides that are applied to the plant's leaves, or by drenching the soil, respectively. Agrochemical sprayings are calendar-based starting in November/ December and continuing through April [19]. The spatial and temporal distributions of coffee rust incidence are not homogeneous across a crop, thus it can be assumed that any total area leaf rust control strategy could be replaced

$\triangle$ Matheus Luiz Jorge Cortez, cortez.agro@gmail.com | ${ }^{1}$ Agricultural Engineering Department, Federal University of Lavras, Lavras, Minas Gerais, Brazil. ${ }^{2}$ Empresa de Pesquisa Agropecuária de Minas Gerais, Epamig sul, Campus da UFLA, Lavras, Minas Gerais, Brazil. ${ }^{3}$ Plant Pathology Department, Federal University of Lavras, Lavras, Minas Gerais, Brazil. 
by focused management in specific areas of disease incidence [2].

Precision agriculture techniques can result in potential benefits in profitability, yield, sustainability, crop quality and traceability, environmental protection, food security and rural economic development [35]. The efficacy of disease management strategies in the field can be accessed using geographic information system (GIS), global navigation satellite system (GNSS), geocomputation, remote sensing, and variable rate application technology integrated with advanced information processing in georeferenced maps during crop growth, development and production [3, 35].

A commonly-used remote sensing method for vegetation studies is the use of vegetation indices. Vegetation indices are mathematical operations involving two or more spectral bands designed to enhance vegetation properties, allowing reliable spatial and temporal inter-comparisons of photosynthetic activity and canopy structure [28]. The method is based on the fact that energy reflected in red and near-infrared (NIR) regions is directly related to photosynthetic activity of the vegetation canopy, as well as the assumption that using two or more spectral bands can substantially minimize the main sources of noise that affect detected variation in vegetation responses [21].

Changes observed in spectral properties within the NIR region may provide information on senescence and vegetation stress issues [31]. The Multi-Spectral Instrument (MSI) sensor embedded in the Sentinel-2 satellite obtains terrestrial surface spectral reflectance information by recording it in 13 different bands of the electromagnetic spectrum. Five of these spectral bands are positioned in distinct bands within the NIR region, and three of these five are located in the rapidly growing reflectance zone known as Red-Edge [20]. Based on reflectance measurements applied to simulate the Sentinel-2 satellite sensor bands, Chemura et al. [13] examined three levels of coffee rust severity in coffee leaves under greenhouse conditions. According to the authors, bands located at the Red-Edge spectral position can be useful for disease detection and coffee crop status evaluation.

In coffee plantations in Brazil, Landsat 7 and 8 images associated with in situ coffee rust data have been used to analyse spectral radiometry behaviour of plants under different irrigation systems [40]. The authors observed that in areas with higher coffee rust incidence under a central pivot and rainfed system, the average reflectance of NIR and green spectral regions was reduced, while reflectance increased in short wave infrared (SWIR) and red wavelengths, when compared to periods with lower coffee rust incidence. Moreover, NDVI generated by Landsat $7 \mathrm{ETM}+$ sensor images were used to evaluate coffee leaf fall caused by coffee rust in Guatemalan coffee plantations
[32]. It was observed that the NDVI standard deviation value in damaged farms increased as the average NDVI value decreased. By analysing annual NDVI changes, it was also reported that disease progression is not homogeneous in crops [32].

Based on the hypothesis that it is possible to detect changes in the spectral behaviour of plants due to the incidence of leaf rust through orbital remote sensing, this study aimed to evaluate the effectiveness of different vegetation indices for remote detection of coffee rust incidence, and to characterize the spectral signature of crops with different levels of disease incidence.

\section{Materials and methods}

\subsection{Area description}

The study area is located in Minas Gerais Agricultural Research Company (EPAMIG) experimental field in Três Pontas city, Minas Gerais state, Brazil. The cultivar present in the area is Catuaí Amarelo IAC-17, a variety susceptible to coffee rust. Plant spacing is $3.5 \mathrm{~m} \times 2.0 \mathrm{~m}$ with 2 plants per pit, and a crop age of 42 years. The approximate central geographical point of the study area has a latitude of $21^{\circ}$ $20^{\prime} 38.36^{\prime \prime} \mathrm{S}$ and a longitude of $45^{\circ} 28^{\prime} 48.51^{\prime \prime} \mathrm{W}$, and the average altitude is around $935 \mathrm{~m}$. The region is classified as Cwa, with dry winters and rainy summers [1].

\subsection{Georeferencing of sample points}

Images obtained by adding the Sentinel-2 MSI sensor to the Spectra Precision SP60 L1/L2 RTK GNSS receiver software provided latitude and longitude data, corresponding to the center of fifty pixels in different spectral bands (Table 1). Subsequently, the GNSS RTK receiver base was placed in the field and the fifty sample points were manually located by walking with the mobile RTK receiver in the sampling area. In each of the fifty identified subareas (measuring $10 \mathrm{~m} \times 10 \mathrm{~m}$ ), a central coffee plant was georeferenced, which was then used to select a further two plants within a radius of approximately $2 \mathrm{~m}$ within the planting line. In total one hundred and fifty coffee plants were evaluated, three plants per sampling point.

\subsection{Crop treatments}

The study area was split into two sections (Fig. 1). The northern section measured approximately 0.57 ha and contained 32 sampling points, while the southern section measured around 0.43 ha and contained 18 sampling points. No rust control was performed in the northern section, however the southern section received a 
Table 1 Spatial and spectral resolution of Sentinel-2 satellite MSI sensor bands [20] used to calculate vegetation indices

\begin{tabular}{llccl}
\hline $\begin{array}{l}\text { Sentinel-2 } \\
\text { band }\end{array}$ & $\begin{array}{l}\text { Denomina- } \\
\text { tion }\end{array}$ & $\begin{array}{l}\text { Spectral } \\
\text { band center } \\
(\mathrm{nm})\end{array}$ & $\begin{array}{l}\text { Band- } \\
\text { width } \\
(\mathrm{nm})\end{array}$ & $\begin{array}{l}\text { Spatial } \\
\text { resolution } \\
(\mathrm{m})\end{array}$ \\
\hline $\begin{array}{l}\text { Coastal } \\
\text { aerosol }\end{array}$ & B01 & 443 & 20 & 60 \\
$\begin{array}{l}\text { Blue } \\
\text { Green }\end{array}$ & B02 & 490 & 65 & 10 \\
Red & B03 & 560 & 35 & 10 \\
Red Edge 1 & B05 & 665 & 30 & 10 \\
Red Edge 2 & B06 & 705 & 15 & 20 \\
Red Edge 3 & B07 & 783 & 15 & 20 \\
Near Infra- & B08 & 842 & 20 & 20 \\
$\quad$ Red & & & 115 & 10 \\
Near Infra- & B8a & 865 & 20 & 20 \\
$\quad$ Red & & & & \\
Water vapour & B09 & 945 & 20 & 60 \\
SWIR-Cirrus & B10 & 1375 & 30 & 60 \\
SWIR 2 & B11 & 1610 & 90 & 20 \\
SWIR 3 & B12 & 2190 & 180 & 20 \\
\hline
\end{tabular}

systemic fungicide containing triazole and strobilurin on 11 December 2018 and 20 February 2019, as well as a leaf application of copper on 8 April 2019. The application of fertiliser was carried out following Guimarães et al. [26], based on soil fertility management and leaf nutrition in coffee culture recommended for Minas Gerais state, Brazil.

\subsection{Field evaluation: coffee rust, defoliation and yield}

Coffee rust was sampled monthly between December 2018 and April 2019 (totalling five separate samples), using a non-destructive method that takes into account plant exposure to solar radiation. For each coffee plant, eight leaves were evaluated; four leaves from different randomly selected plagiotropic branches on the north-facing side of the plant (i.e. higher insolation levels), and four leaves from different plagiotropic branches on the south-facing side of the plant (lower insolation levels) [15]. Therefore, a total of 24 leaves were evaluated per subarea. Leaves of the 3rd and 4th pair of plagiotropic branches in the middle third of the plants were assessed according to the methodology proposed by Lima [36]. The percentage of coffee rust incidence for each subarea was obtained by dividing the total number of leaves with recorded coffee rust signals by the total number of leaves evaluated in the subarea ( 24 leaves), and multiplied by one hundred.

Defoliation was determined using strands positioned at two points on one plagiotropic branch of each of the one hundred and fifty coffee plants. Leaf fall was recorded in each monthly assessment following the initial number of leaves counted in December 2018, totalling five samples. These leaf drop data were then transformed into a percentage of defoliation.

Fruit harvest was carried out on 2 July 2019 with a portable Nakashi DL 262-MT2L gasoline machine. A cloth was placed on the floor around the plants to facilitate the
Fig. 1 Study area indicating the location of Minas Gerais state within Brazil, and the south/southwest region of the federative unit (left), the area of Três Pontas city (bottom right), and the plantation area in the EPAMIG experimental fieldsite, showing the sampling pixels (subareas) (top right)

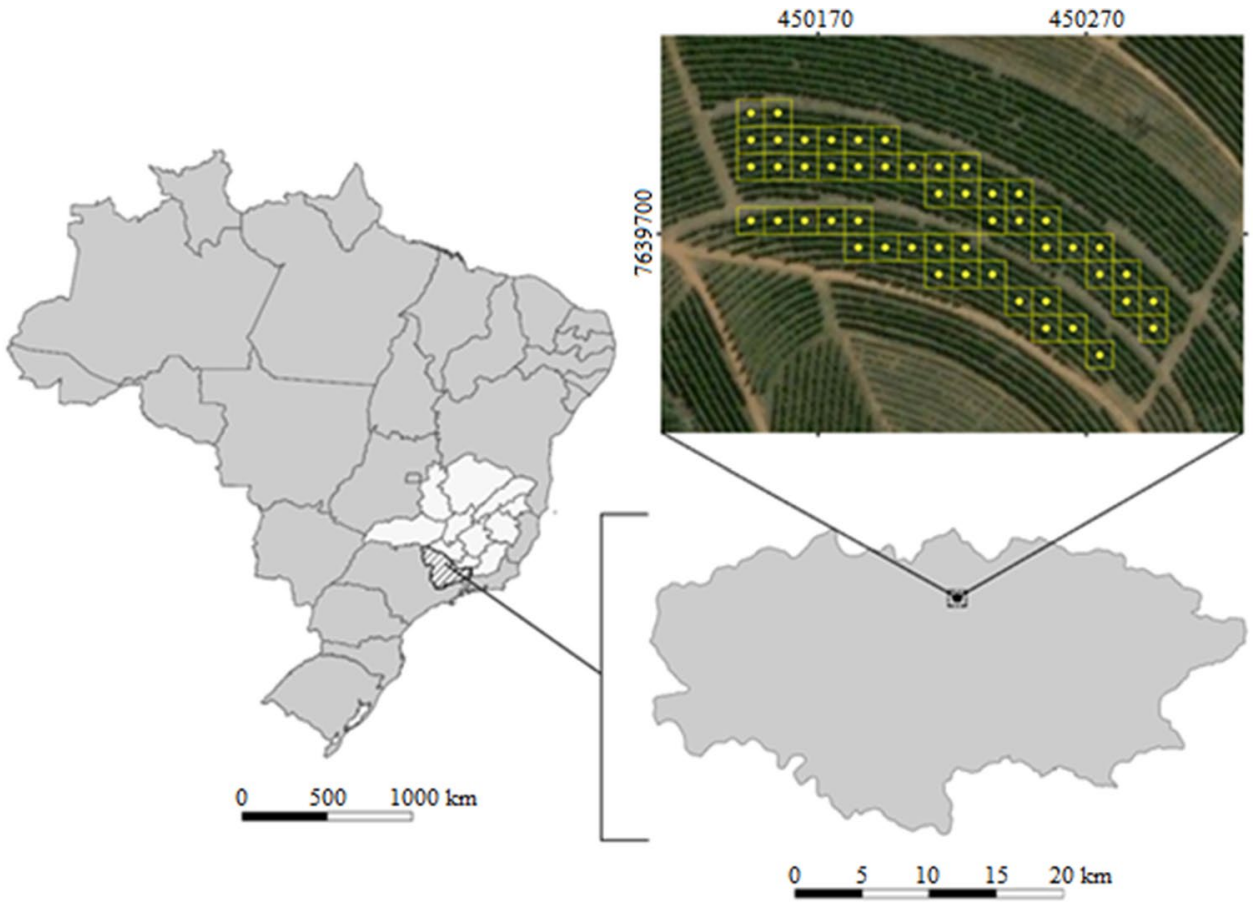

SN Applied Sciences A SPRINGER NATURE journa 
collection of the fallen fruits. The volume of fruits from the three plants in each subarea was measured using a graduated bucket, meaning that the volume assigned to each of the fifty subareas corresponded to liters per three plants. Fruits were collected from all one hundred and fifty plants that were previously evaluated for coffee rust incidence levels.

\subsection{Multispectral data}

The orbital data captured by the Sentinel-2 satelliteembedded MSI sensor was obtained by a free download available from the United States Geological Survey [44] collection. Sentinel-2 scenes were selected using the criteria of least atmospheric interference and closest proximity to date of crop rust sampling (Table 2).

\subsection{Sentinel-2 digital image processing}

Digital images were processed using the Dark Object Subtraction (DOS) method [11, 12]. Correction by the DOS method is carried out by estimating the atmospheric interference in each spectral band, performing calculations to transform the digital number into radiance values, and then to surface reflectance values. Minimum and maximum radiance, top-level irradiance, and sensor gain were necessary variables for calculations, and varied for different bands. Additionally, other factors that depend on the image date were included, such as Earth-Sun distance and solar elevation angle [27].

\subsection{Vegetation indices calculations and Pearson's correlations}

Vegetation indices (Table 3) using different relationships between Sentinel-2 spectral bands were calculated. The vegetation indices selected provide data on plant canopy such as leaf area, plant leaf moisture and chlorophyll content.

Vegetation index calculations (Table 3) were performed for 7 selected Sentinel-2 images for correlation with coffee rust incidence, defoliation and yield data. Another Sentinel-2 image (November 2018) was selected for index calculations for use in comparison with monthly rainfall intensity data. To perform the correlations, values were extracted from each index corresponding to the 50

Table 2 Dates that in situ data were obtained, respective orbital data used for correlation analysis and cloud coverage of Sentinel-2 images [44]

\begin{tabular}{lllllllll}
\hline Data & August & September & November & December & January & February & March & April \\
\hline In situ & - & - & - & $2018 / 12 / 14$ & $2019 / 01 / 14$ & $2019 / 02 / 15$ & $2019 / 03 / 15$ & $2019 / 04 / 19$ \\
Orbitals & $2018 / 08 / 20$ & $2018 / 09 / 09$ & $2018 / 11 / 28$ & $2018 / 12 / 13$ & $2019 / 01 / 17$ & $2019 / 02 / 01$ & $2019 / 03 / 08$ & $2019 / 04 / 22$ \\
Cloud cover $(\%)$ & $<10$ & $<10$ & $<10$ & $<10$ & $<20$ & $<10$ & $<10$ & $<10$ \\
\hline
\end{tabular}

Table 3 Vegetation indices calculated to correlate with leaf rust incidence, defoliation and yield data obtained from field samples, spectral bands necessary for index calculations and authors who developed/adapted them

\begin{tabular}{|c|c|c|}
\hline Index & Formula & Source \\
\hline Normalized Difference Vegetation Index & $N D V I=\frac{(B 8-B 4)}{(B 8+B 4)}$ & Rouse et al. [42] \\
\hline Normalized Difference Moisture Index (B11) & $N D M I(B 11)=\frac{(B 8-B 11)}{(B 8+B 11)}$ & Wilson and Sader [46] \\
\hline Normalized Difference Moisture Index (B12) & $N D M I(B 12)=\frac{(B 8-B 12)}{(B 8+B 12)}$ & Wilson and Sader [46] \\
\hline Renormalized Normalized Difference Vegetation Index & $R N D V I=\frac{(B 8-B 4)}{\sqrt{B 8+B 4}}$ & Gitelson and Merzlyak [23] \\
\hline Inverted Red-Edge Chlorophyll Index & $I R E C I=\frac{(B 8-B 4)}{\sqrt{B 6 / B 5}}$ & Frampton et al. [22] \\
\hline Normalized Difference Vegetation Index (RE1) & $N D V I(R E 1)=\frac{(B 8-B 5)}{(B 8+B 5)}$ & Gitelson and Merzlyak [23] \\
\hline Red-Edge Chlorophyll Index & $C l(R E 1)=(B 8 / B 5)-1$ & Gitelson et al. [24] \\
\hline $\begin{array}{l}\text { Transformed Chlorophyll Absorption Ratio Index/Optimized Soil- } \\
\text { Adjusted Vegetation Index }\end{array}$ & $\frac{T C A R I}{O S A V I}=\frac{3 *[(B 6-B 5)-0.2 *(B 6-B 3) *(B 6 / B 5)]}{\{[(1+0.16) *(B 6-B 5)] / B 6+B 5+0.16\}}$ & $\begin{array}{l}\text { Rondeaux et al. [41], } \\
\text { Daughtry et al. [17], Wu } \\
\text { et al. [47] }\end{array}$ \\
\hline $\begin{array}{l}\text { Modified Chlorophyll Absorption Ratio Index/Optimized Soil- } \\
\text { Adjusted Vegetation Index }\end{array}$ & $\frac{M C A R I}{O S A V I}=\frac{[(B 6-B 5)-0.2 *(B 6-B 3)] *(B 6 / B 5)}{\{[(1+0.16) *(B 6-B 5)] / B 6+B 5+0.16\}}$ & $\begin{array}{l}\text { Rondeaux et al. [41], } \\
\text { Daughtry et al. [17], Wu } \\
\text { et al. [47] }\end{array}$ \\
\hline Modified Simple Ratio (RE1) & $\operatorname{MSR}(R E 1)=\frac{[(B 8 / B 5)-1]}{\sqrt{(B 8 / B 5)+1}}$ & Chen [14], Wu et al. [47] \\
\hline
\end{tabular}


georeferenced subareas in the coffee crop area selected for rust sampling (i.e. the 50 pixels of highest spatial resolution bands of Sentinel-2 MSI images). Pearson's correlations (Fig. 2) were performed between in situ data and vegetation indices values extracted from the 18 sampling points in the southern section (with coffee rust chemical control). The same procedure was performed for the 32 points in the northern section (without coffee rust chemical control).

In order to evaluate spectral behaviour in the south and north sections, reflectance values of each 50 sample points were extracted from all 13 spectral bands in the Sentinel-2 images. For each of the 13 bands, monthly mean reflectance values of the 32 northern sample points were calculated. The same procedure was performed for the 18 southern sample points. Student's $t$-tests were then performed to compare monthly averages of areas with and without leaf rust chemical control.

\subsection{Meteorological in situ data}

To better understand the coffee plant's spectral response to coffee rust, monthly rainfall data were used to compare with the monthly vegetation indices data. Rainfall intensity ( $\mathrm{mm} / \mathrm{month}$ ) was measured with a rain gauge from three conventional weather stations located in the cities of Machado, Lavras and São Lourenço, that surround the EPAMIG experimental fieldsite in Minas Gerais state, Brazil [30]. With these data, rainfall intensity interpolation was performed by using an inverse distance weighting method [45].

\section{Results}

\subsection{Spatial-temporal coffee rust distribution}

An increase in coffee rust incidence was recorded over the months of assessment, most notably in the area where the disease was not controlled (Fig. 3). Coffee rust incidence classes were defined in order to facilitate the visualization of rust spatiotemporal progress (Fig. 4).

\subsection{Correlation of data derived from Sentinel 2 with field data}

Pearson's correlation indicated an interaction between levels of coffee rust incidence and the vegetation indices

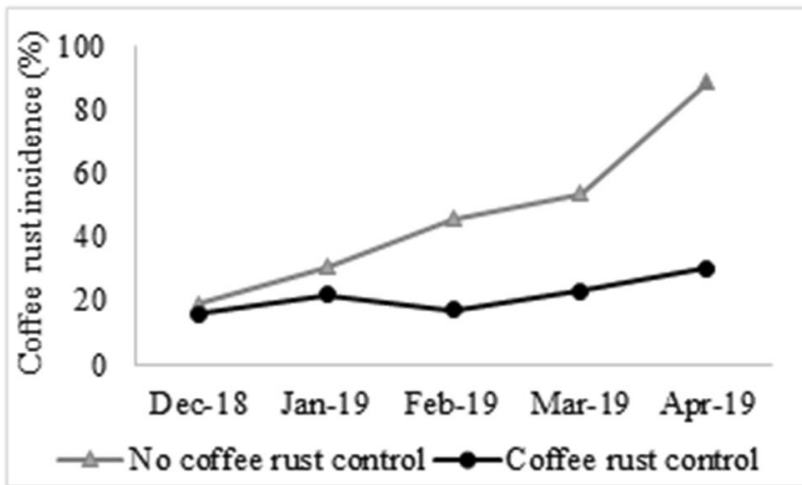

Fig. 3 Coffee rust incidence percentage between December 2018 and April 2019 in areas with and without chemical control in the EPAMIG experimental fieldsite, Três Pontas city, Minas Gerais state, Brazil

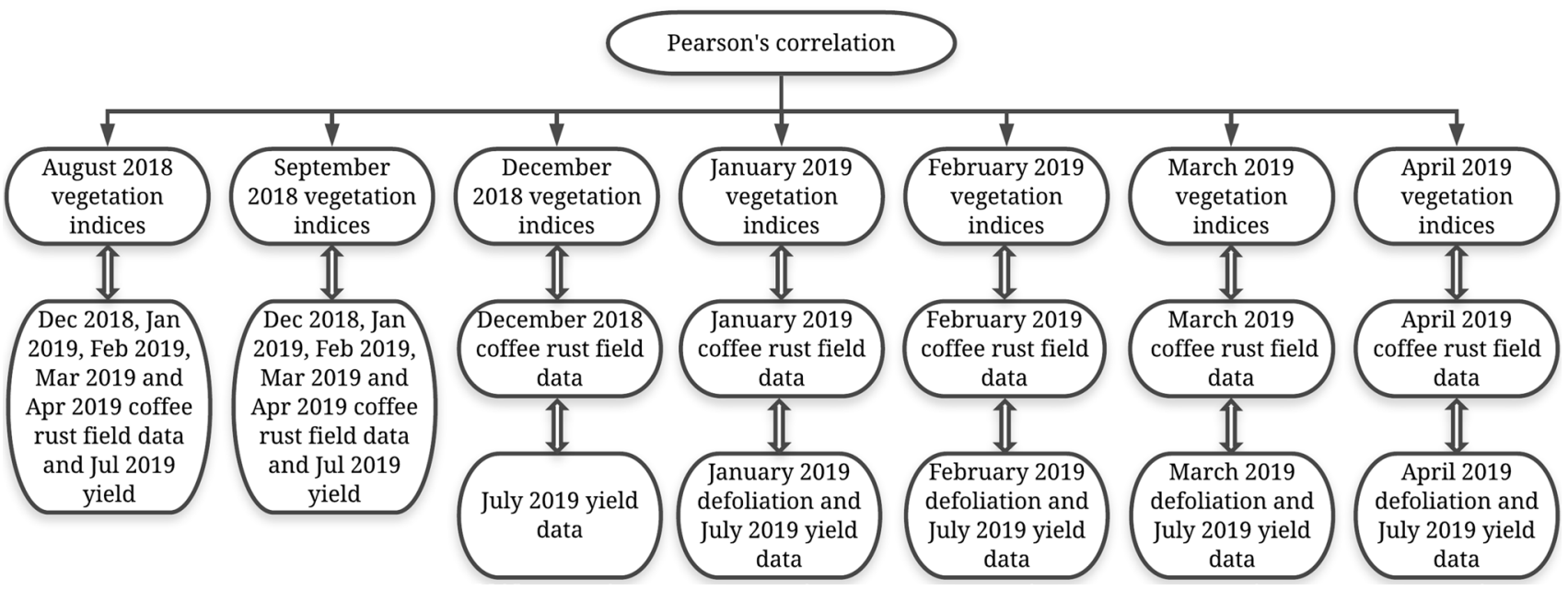

Fig. 2 Correlations between field data sampled in EPAMIG experimental fieldsite in Três Pontas city and vegetation indices calculated with Sentinel-2 images 

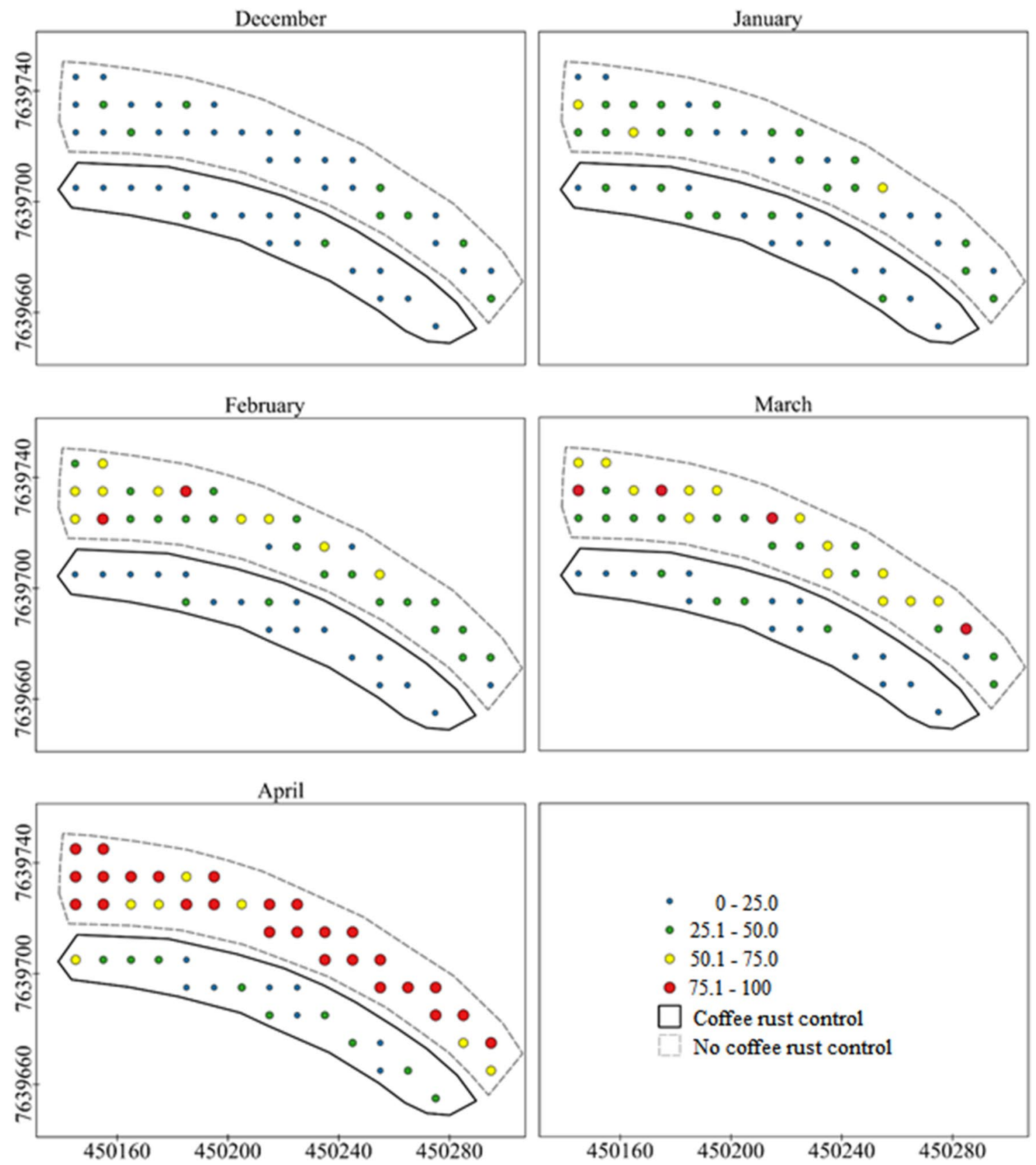

Fig. 4 Coffee rust incidence percentage in crop subareas over time in control and uncontrolled sections (continuous and dashed lines, respectively) in the EPAMIG experimental fieldsite, Três Pontas city, Minas Gerais state, Brazil

calculated for each respective month of evaluation. It was noted that in February 2019 negative correlations were reported between various vegetation indices and coffee rust incidence in the northern section of the study site (Table 4).

The vegetation indices calculated with the February 2019 images using spectral bands in NIR (B08) and RedEdge 1 (B05) presented the highest correlation values with leaf rust data sampled in the respective month [NDVI(RE1) $r=-0.562 ; \mathrm{Cl}(\mathrm{RE} 1) \mathrm{r}=-0.573$; MSR(RE1) $r=-0.569]$. For
NDMI indices calculated using NIR band (B08) and one of the bands in SWIR position (B11 or B12), we obtained, respectively, moderate and weak correlations for February $2019(r=-0.518$ and $r=-0.481)$, and moderate for April $2019(r=-0.502$ and $r=-0.519)$.

The yield harvested in July 2019 had a moderate positive correlation $(r=0.555)$ with coffee rust incidence reported in April 2019 in the sampling section without any chemical control. Furthermore, the IRECl vegetation index generated from images recorded in August and 
September 2018 also correlated positively with leaf rust assessment data obtained in February and March 2019 (Tables 5 and 6).

\subsection{Reflectance and vegetation index averages in areas with and without coffee rust control}

By analysing average monthly reflectances for the different bands of the electromagnetic spectrum in both

Table 4 Pearson's correlations ( $r$ ) between different vegetation indices, yield and defoliation coffee rust incidence between December 2018 and April 2019, in sampling areas with chemical control measures (c), and without chemical control measures (nc)

\begin{tabular}{lllrrrrrrrr}
\hline Data & Dec $(\mathrm{nc})$ & Dec (c) & Jan $(\mathrm{nc})$ & \multicolumn{1}{c}{$\operatorname{Jan}(\mathrm{c})$} & Feb (nc) & Feb (c) & Mar (nc) & Mar (c) & Apr (nc) & Apr (c) \\
\hline YIELD & -0.132 & -0.390 & -0.291 & -0.406 & -0.082 & -0.173 & 0.243 & 0.034 & $\mathbf{0 . 5 5 5}$ & 0.307 \\
DEFOLIATION & - & - & $\mathbf{0 . 3 8 4}$ & 0.113 & 0.230 & 0.030 & 0.220 & 0.116 & 0.268 & 0.131 \\
NDVI & -0.173 & -0.316 & -0.036 & -0.295 & -0.313 & 0.251 & -0.166 & -0.001 & 0.257 & -0.435 \\
NDMI(B11) & 0.077 & -0.292 & -0.039 & -0.451 & $-\mathbf{0 . 5 1 8}$ & -0.007 & -0.266 & -0.078 & 0.122 & $-\mathbf{0 . 5 0 2}$ \\
NDMI(B12) & 0.116 & -0.218 & -0.100 & -0.450 & $-\mathbf{0 . 4 8 1}$ & -0.039 & -0.175 & 0.007 & 0.092 & $-\mathbf{0 . 5 1 9}$ \\
RNDVI & -0.132 & -0.338 & -0.033 & -0.375 & $-\mathbf{0 . 4 2 6}$ & 0.236 & -0.288 & -0.087 & 0.242 & -0.448 \\
IRECI & -0.211 & -0.360 & 0.262 & 0.039 & -0.124 & 0.210 & -0.040 & -0.249 & 0.155 & -0.361 \\
NDVI(RE1) & 0.193 & -0.212 & -0.178 & -0.403 & $-\mathbf{0 . 5 6 2}$ & 0.031 & $-\mathbf{0 . 3 7 8}$ & -0.037 & 0.133 & -0.461 \\
CI(RE1) & 0.199 & -0.220 & -0.182 & -0.401 & $-\mathbf{0 . 5 7 3}$ & 0.034 & $-\mathbf{0 . 3 7 1}$ & -0.034 & 0.137 & -0.426 \\
TCARI/OSAVI & -0.078 & 0.201 & 0.189 & 0.310 & $\mathbf{0 . 4 7 3}$ & -0.127 & 0.269 & -0.087 & -0.219 & 0.445 \\
MCARI/OSAVI & 0.220 & -0.127 & -0.154 & -0.283 & $-\mathbf{0 . 4 7 4}$ & -0.050 & $-\mathbf{0 . 3 8 5}$ & 0.019 & 0.135 & -0.359 \\
MSR(RE1) & 0.197 & -0.217 & -0.181 & -0.402 & $-\mathbf{0 . 5 6 9}$ & 0.033 & $-\mathbf{0 . 3 7 4}$ & -0.035 & 0.135 & -0.440 \\
\hline
\end{tabular}

Significant $r$ values $(p<0.05)$ are in bold

Table 5 Pearson's correlations (r) between vegetation indices calculated with August images with coffee rust incidence data and yield data from sample points in the area without chemical control

\begin{tabular}{lrrrrrr}
\hline August indices & \multicolumn{1}{l}{ Dec } & \multicolumn{1}{l}{ Jan } & \multicolumn{1}{l}{ Feb } & \multicolumn{1}{l}{ Mar } & \multicolumn{1}{l}{ Apr } & \multicolumn{1}{c}{ Yield } \\
\hline NDVI & 0.041 & -0.019 & 0.221 & 0.246 & 0.054 & -0.134 \\
NDMI(B11) & 0.013 & -0.112 & -0.114 & 0.241 & 0.137 & 0.090 \\
NDMI(B12) & -0.058 & -0.219 & -0.143 & 0.236 & 0.060 & 0.171 \\
RNDVI & 0.080 & -0.023 & 0.266 & 0.304 & 0.114 & -0.096 \\
IRECI & 0.138 & 0.024 & $\mathbf{0 . 5 6 6}$ & $\mathbf{0 . 4 4 7}$ & 0.193 & -0.062 \\
NDVI(RE1) & 0.010 & -0.166 & -0.262 & 0.096 & 0.056 & 0.051 \\
CI(RE1) & 0.016 & -0.147 & -0.240 & 0.102 & 0.077 & 0.058 \\
TCARI/OSAVI & 0.011 & 0.052 & 0.169 & -0.090 & -0.081 & 0.011 \\
MCARI/OSAVI & 0.029 & -0.038 & $-\mathbf{0 . 4 7 7}$ & -0.209 & -0.021 & -0.007 \\
MSR(RE1) & 0.013 & -0.155 & -0.249 & 0.100 & 0.068 & 0.055 \\
\hline
\end{tabular}

Significant values $(p<0.05)$ are in bold

\begin{tabular}{lrrrrrr}
\hline September indices & \multicolumn{1}{l}{ Dec } & \multicolumn{1}{l}{ Jan } & \multicolumn{1}{l}{ Feb } & \multicolumn{1}{l}{ Mar } & \multicolumn{1}{l}{ Apr } & \multicolumn{1}{c}{ Yield } \\
\hline NDVI & 0.021 & -0.064 & 0.120 & 0.194 & 0.068 & -0.100 \\
NDMI(B11) & 0.036 & -0.077 & -0.118 & 0.235 & 0.171 & 0.069 \\
NDMI(B12) & -0.031 & -0.060 & -0.165 & 0.190 & 0.090 & 0.019 \\
RNDVI & 0.057 & -0.033 & 0.198 & 0.249 & 0.118 & -0.100 \\
IRECI & 0.097 & 0.027 & $\mathbf{0 . 4 9 3}$ & $\mathbf{0 . 3 8 9}$ & 0.256 & -0.074 \\
NDVI(RE1) & 0.051 & -0.121 & -0.204 & 0.040 & -0.010 & 0.036 \\
CI(RE1) & 0.059 & -0.131 & -0.205 & 0.053 & 0.018 & 0.063 \\
TCARI/OSAVI & -0.002 & 0.135 & 0.131 & -0.110 & 0.009 & 0.035 \\
MCARI/OSAVI & 0.042 & 0.090 & -0.230 & -0.143 & -0.112 & -0.115 \\
MSR(RE1) & 0.056 & -0.127 & -0.205 & 0.048 & 0.006 & 0.052 \\
\hline
\end{tabular}

Significant values $(p<0.05)$ are in bold
Table 6 Pearson's correlations (r) between vegetation indices calculated with September images with coffee rust incidence data and yield data from sample points in the area without chemical control 
the northern and southern sections, it was observed that there were higher average reflectances in the Red-Edge/ NIR region (Fig. 5). It was also noted that for the spectral region in Red-Edge/NIR, there were reflectance peaks for the month of February 2019 in both sections. However, average reflectances at RE2 $(740 \mathrm{~nm}), \operatorname{RE} 3(783 \mathrm{~nm})$, NIR-8 $(842 \mathrm{~nm})$ and NIR-8a $(865 \mathrm{~nm})$ were higher in the northern area with no rust control. By analysing isolated bands, two SWIR bands were found to have the highest reflectance in December 2018, indicating a lower moisture content in the vegetation canopy.

Student's $t$ test showed that the average reflectance of RE2 (B06), RE3 (B07), NIR-8 and NIR-8a bands in the northern and southern sampling sections did not differ from each other in December 2018. However, reflectance averages became statistically different when comparing the north and south sample areas due to increased occurrence of coffee rust in January and February 2019 , corresponding to higher reflectance in the northern section where the incidence of leaf rust was higher (Table 7).

The tested vegetation indices responded differently to rainfall intensity (Fig. 6). The curve of indices NDVI, NDMI(B11), NDMI(B12), RNDVI, NDVI(RE1), CI(RE1), MCARI/ OSAVI and MSR(RE1) are similar and appeared to correspond with the rainfall intensity curve with a delay of
Fig. 5 Average monthly reflectance of Sentinel-2 spectral bands in the two areas (with and without coffee rust control measures) in the EPAMIG experimental fieldsite at Três Pontas city, Minas Gerais state, Brazil
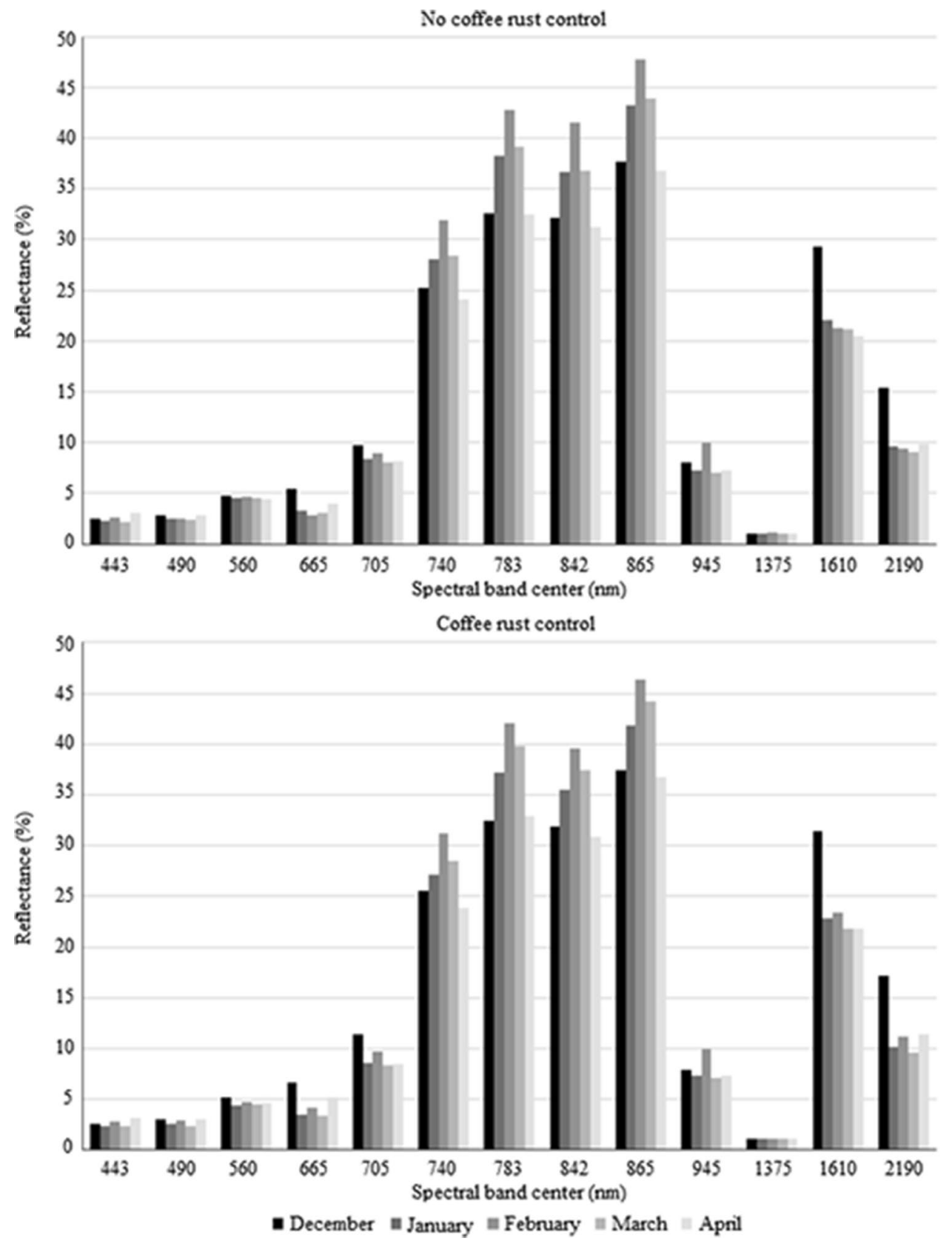
Table 7 Spectral bands reflectance averages of areas with (c) and without (nc) coffee rust control and Student's t-test results ('ns' equal to not significant) for independent samples (comparison of means)

\begin{tabular}{|c|c|c|c|c|c|c|c|c|c|c|c|c|c|c|c|c|}
\hline \multirow[t]{3}{*}{ Bands } & \multirow{3}{*}{$\begin{array}{l}\text { Band } \\
\text { center } \\
(\mathrm{nm})\end{array}$} & \multicolumn{3}{|c|}{ December } & \multicolumn{3}{|c|}{ January } & \multicolumn{3}{|c|}{ February } & \multicolumn{3}{|l|}{ March } & \multicolumn{3}{|l|}{ April } \\
\hline & & \multicolumn{2}{|l|}{ Mean } & \multirow[t]{2}{*}{$p$ value } & \multicolumn{2}{|l|}{ Mean } & \multirow[t]{2}{*}{$p$ value } & \multicolumn{2}{|l|}{ Mean } & \multirow[t]{2}{*}{$p$ value } & \multicolumn{2}{|l|}{ Mean } & \multirow[t]{2}{*}{$p$ value } & \multicolumn{2}{|l|}{ Mean } & \multirow[t]{2}{*}{$p$ value } \\
\hline & & c & $\mathrm{nc}$ & & c & $\mathrm{nc}$ & & c & $\mathrm{nc}$ & & c & $\mathrm{nc}$ & & c & $\mathrm{nc}$ & \\
\hline B01 & 443 & 2.58 & 2.46 & $\leq 0.01$ & 2.33 & 2.29 & ns & 2.76 & 2.64 & $\leq 0.01$ & 2.29 & 2.21 & $\leq 0.01$ & 3.13 & 3.08 & ns \\
\hline B02 & 490 & 3.07 & 2.79 & $\leq 0.05$ & 2.52 & 2.48 & ns & 2.89 & 2.55 & $\leq 0.01$ & 2.38 & 2.42 & ns & 3.08 & 2.90 & ns \\
\hline B03 & 560 & 5.12 & 4.75 & $\leq 0.05$ & 4.35 & 4.50 & $\leq 0.01$ & 4.77 & 4.60 & ns & 4.47 & 4.60 & ns & 4.57 & 4.49 & ns \\
\hline B04 & 665 & 6.70 & 5.41 & $\leq 0.01$ & 3.50 & 3.30 & $\leq 0.05$ & 4.17 & 2.88 & $\leq 0.01$ & 3.33 & 3.05 & ns & 5.22 & 3.93 & $\leq 0.01$ \\
\hline B05 & 705 & 11.42 & 9.70 & $\leq 0.01$ & 8.58 & 8.41 & $\leq 0.05$ & 9.67 & 8.92 & $\leq 0.01$ & 8.30 & 8.02 & $\leq 0.05$ & 8.45 & 8.19 & ns \\
\hline B06 & 740 & 25.50 & 25.21 & ns & 27.14 & 28.10 & $\leq 0.01$ & 31.17 & 31.96 & $\leq 0.01$ & 28.46 & 28.45 & ns & 23.86 & 24.16 & $\leq 0.05$ \\
\hline B07 & 783 & 32.48 & 32.65 & ns & 37.18 & 38.19 & $\leq 0.01$ & 42.07 & 42.73 & $\leq 0.01$ & 39.83 & 39.14 & $\leq 0.01$ & 32.86 & 32.44 & ns \\
\hline B08 & 842 & 31.90 & 32.11 & ns & 35.54 & 36.61 & $\leq 0.01$ & 39.61 & 41.48 & $\leq 0.01$ & 37.46 & 36.75 & $\leq 0.01$ & 30.91 & 31.19 & ns \\
\hline B8a & 865 & 37.45 & 37.67 & ns & 41.84 & 43.17 & $\leq 0.01$ & 46.35 & 47.73 & $\leq 0.01$ & 44.25 & 43.85 & ns & 36.81 & 36.75 & ns \\
\hline B09 & 945 & 7.89 & 8.01 & $\leq 0.01$ & 7.28 & 7.28 & ns & 9.98 & 9.93 & ns & 7.08 & 7.05 & ns & 7.31 & 7.30 & ns \\
\hline B10 & 1375 & 1.08 & 1.08 & ns & 1.05 & 1.05 & ns & 1.15 & 1.16 & $\leq 0.01$ & 1.06 & 1.05 & $\leq 0.01$ & 1.08 & 1.08 & ns \\
\hline B11 & 1610 & 31.44 & 29.29 & $\leq 0.01$ & 22.80 & 22.11 & $\leq 0.01$ & 23.35 & 21.29 & $\leq 0.01$ & 21.82 & 21.11 & $\leq 0.01$ & 21.83 & 20.47 & $\leq 0.05$ \\
\hline B12 & 2190 & 17.14 & 15.42 & $\leq 0.01$ & 10.15 & 9.62 & $\leq 0.01$ & 11.16 & 9.36 & $\leq 0.01$ & 9.64 & 9.12 & $\leq 0.01$ & 11.34 & 9.85 & $\leq 0.01$ \\
\hline
\end{tabular}

around 3 months, however, with different intensities. For indices calculated with SWIR bands, the pattern was observed more sharply. The vegetation index TCARI/OSAVI presented this same pattern in inverted form. For the IRECI case, the response to rainfall seemed to be faster, following the rainfall intensity curve with an interval of less than 1 month.

\section{Discussion}

This study aimed to evaluate the effectiveness of different vegetation indices calculated from Sentinel-2 MSI images for remote detection of coffee rust incidence symptoms, and to characterize the spectral signature of crops with different coffee rust incidence levels. Field data were obtained for comparative analysis with orbital data on several dates. Rainfall intensity data were estimated for the crop area to help understand the spectral behaviour of coffee plants with different disease intensity.

\subsection{Spatial-temporal leaf rust distribution}

Outbreaks of coffee rust were detected at the start of field evaluations, and from these affected spots the area that had not received chemical control was further infected by the disease. Hemileia vastatrix uredospores are dispersed inside the canopy by raindrops, through the spread of water flow in the infected leaves during rainfall [34]. In short, the sudden increase in the magnitude of disease incidence is the result of its effective dispersal through water $[6,38]$. However, wind gusts also promote uredospore dispersal across crops in full sun. Such dispersion is favoured during dry days with low relative humidity [7]. As a result, through the kriging map analysis it was observed that distribution and incidence intensity of coffee leaf rust were not homogeneous throughout the coffee field [2].

\subsection{Correlation of data derived from Sentinel 2 with field data}

Vegetation indices for remote disease monitoring may aid crop management. Through correlations between vegetation indices and field data for the same month, it was found that February 2019 is the best month to extract information on conditions of $H$. vastatrix infestation in coffee crops. In addition, it seemed appropriate to use vegetation indices that make use of bands in the NIR/Red-Edge region. Spectral bands positioned in the Red-Edge region appear to have greater sensitivity for identifying changes in the plant canopy when dealing with leaf diseases [9, $13,18,50]$.

The IRECI vegetation index calculated using MSI Sentinel-2 images from August and September 2018 was positively correlated with the February 2019 rust incidence data (IREClaug $r=0.566$ and IREClsep $r=0.493$ ). This observation may help in the localized control of coffee leaf rust, since in the subareas with higher IRECI values, higher levels of leaf rust incidence were observed. Furthermore, coffee leaf rust incidence data from April 2019 correlated positively with yield data collected in July 2019. The positive relationship between plant yield and coffee rust incidence 


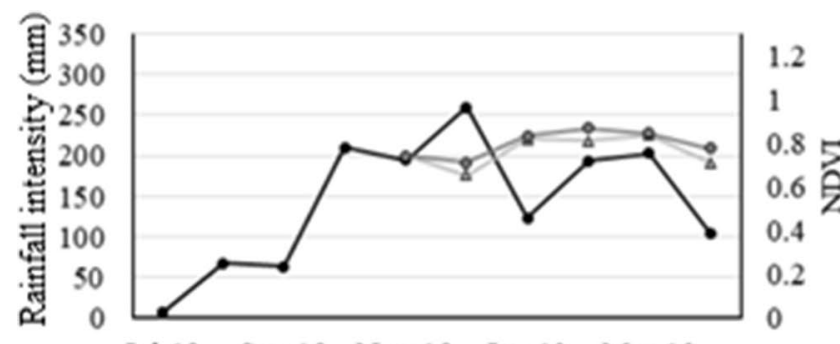

Jul-18 Sep-18 Nov-18 Jan-19 Mar-19
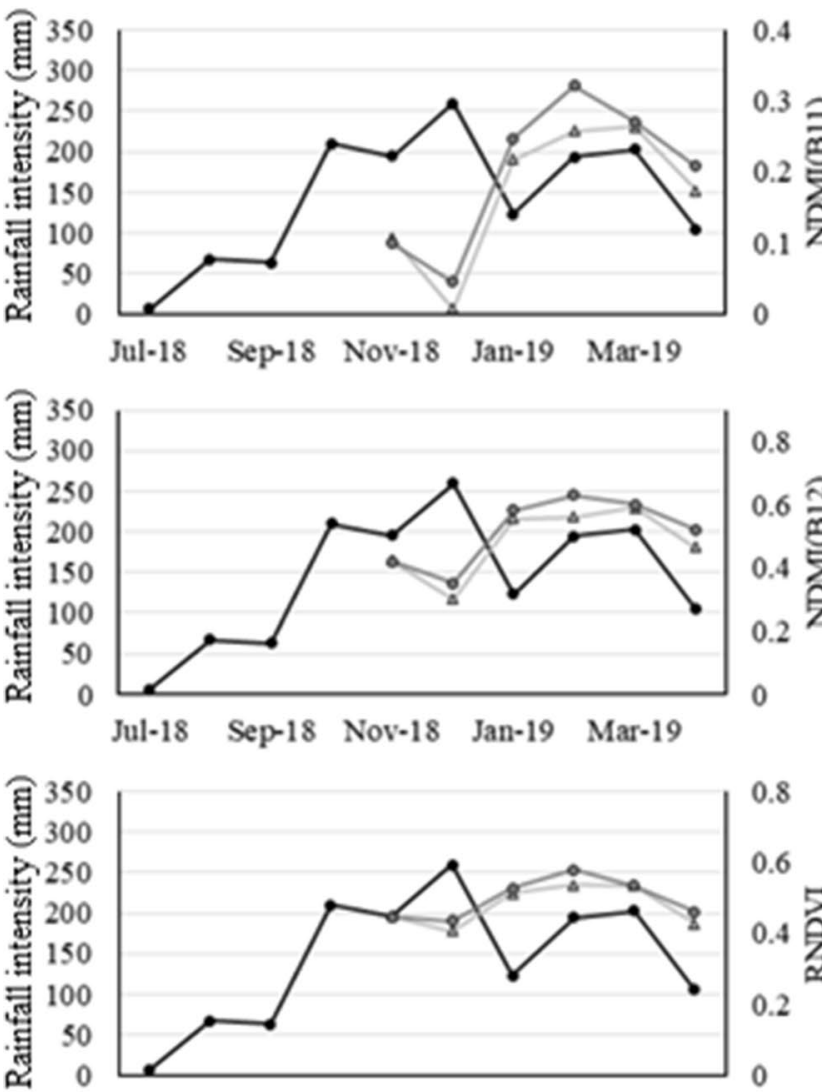

Jul-18 Sep-18 Nov-18 Jan-19 Mar-19
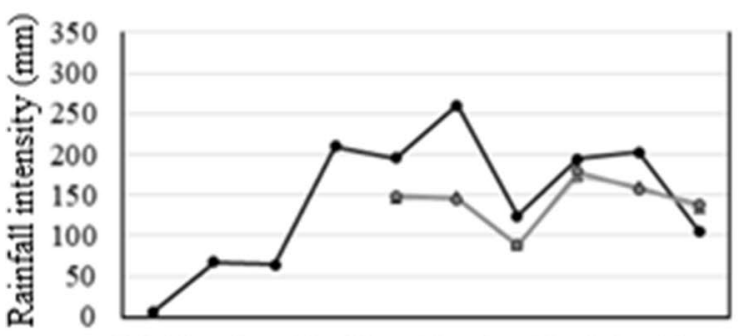

Jul-18 Sep-18 Nov-18 Jan-19 Mar-19

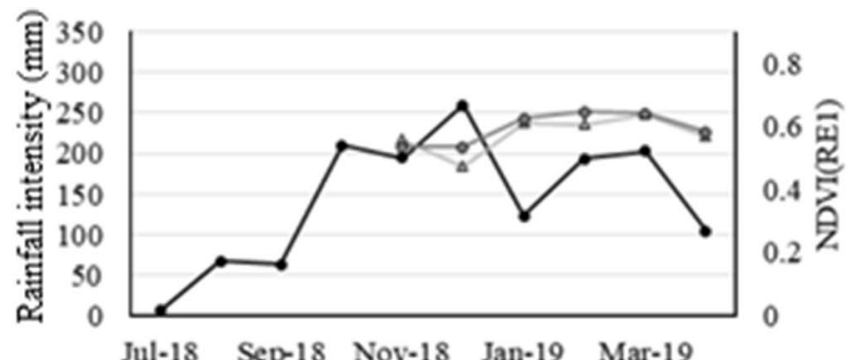

Jul-18 Sep-18 Nov-18 Jan-19 Mar-19
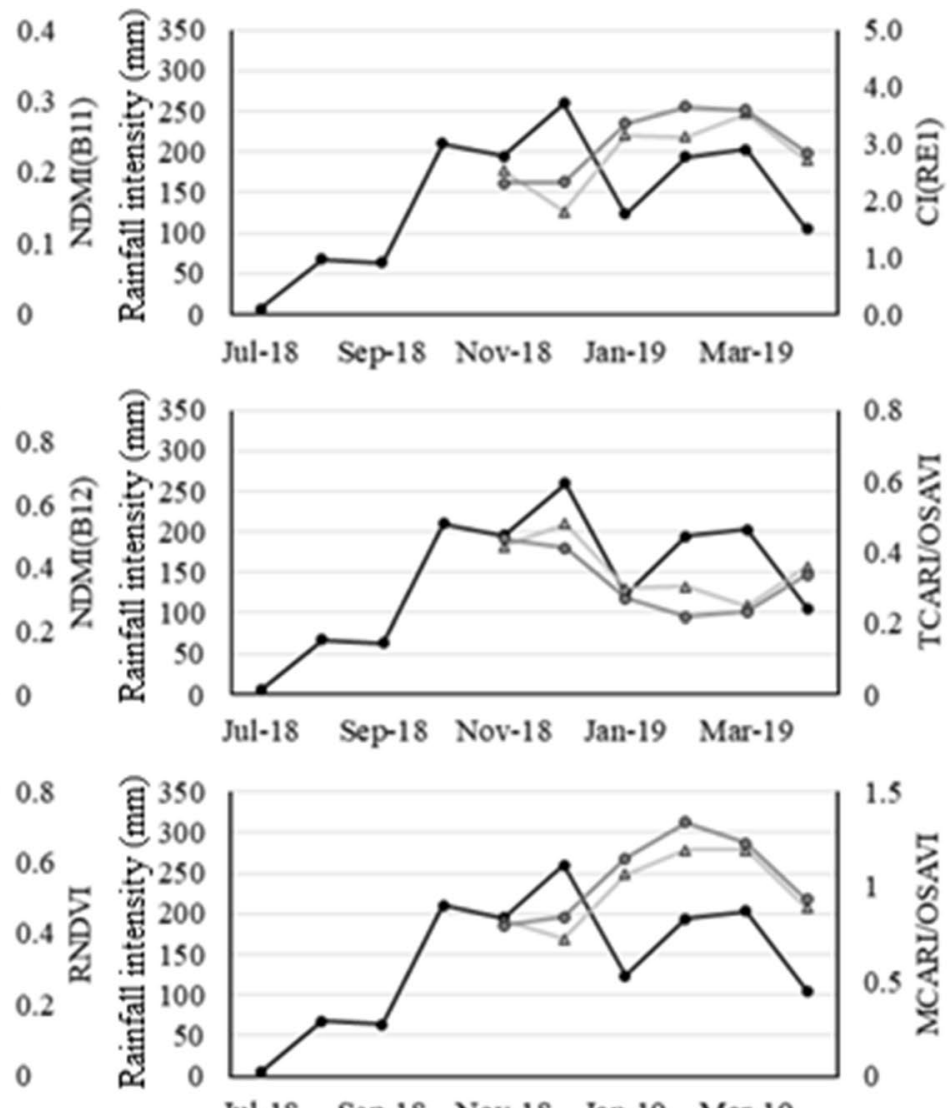

Jul-18 Sep-18 Nov-18 Jan-19 Mar-19

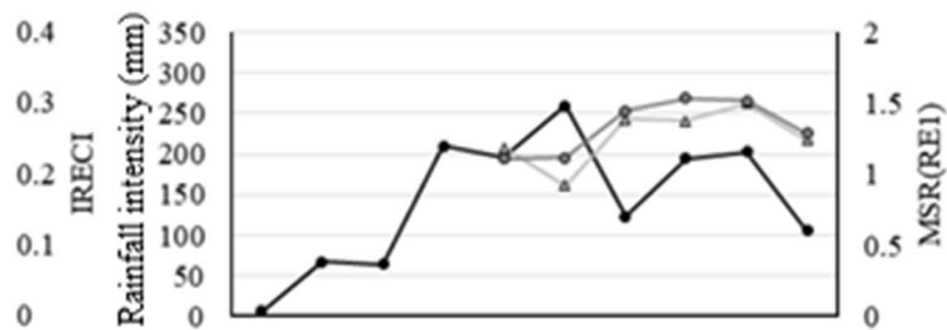

Jul-18 Sep-18 Nov-18 Jan-19 Mar-19

$\rightarrow$ Rainfall intensity $\_-$Index value on area without coffee rust control $\_-$Index value on area with coffee rust control

Fig. 6 Rainfall intensity and vegetation index curves of monthly mean values in areas with and without chemical control of coffee leaf rust at Três Pontas city, Minas Gerais state, Brazil 
has been widely discussed in the specialized literature [4, $5,8,10,16,37,43,48]$.

\subsection{Reflectance and vegetation index averages in areas with and without leaf rust control}

This study reported higher average reflectances in the area with chemical control measures in February 2019 for bands RE2, RE3 and the two NIR plateau bands, relative to the area without chemical control. According to Knipling [33], reflectance in the NIR region is a result of the scattering of electromagnetic radiation that occurs due to existing interface areas in the transition between cell walls. Furthermore, the mesophyll deterioration leads to the reduction of existing air cavities, with a consequent reduction of reflectance in the NIR region. However, the author also notes that at the beginning of the leaf senescence process, there is an increase in these interface areas due to the separation of adjacent cells, as well as the distancing of living cell content from cell walls. Therefore, February 2019 may have marked the beginning of the leaf senescence process, as evidenced by increased reflectance in the Red-Edge/NIR region, most notably in the northern fieldsite (without chemical control) which had higher coffee leaf rust incidence.

High reflectance values were observed for bands in the SWIR region for both areas in December 2018. The wavelengths in the SWIR region are absorbed by water, meaning that when vegetation suffers from a water deficit, there is increased reflectance in the spectral bands positioned in this region of the electromagnetic spectrum $[29,31,46]$. Therefore, despite the rainfall regime beginning in October 2018, the leaf structure had not yet shown to have water at its maximum potential.

Vegetation indices apparently responded to rainfall after approximately three months, with the exception of IRECl, which appears to have responded in less than a month. IRECI provides information on the chlorophyll content of leaves at a ratio close to $1: 1 \mathrm{~g} / \mathrm{m}^{2}$ and still works well as a leaf area index [22]. Decreasing leaf water potential leads to decreased chlorophyll content, as this pigment is sensitive to increased environmental stress, especially salinity and drought [25]. Therefore, there may be a relationship with the occurrence of this observed behaviour and more detailed studies are needed to obtain better understanding.

\section{Conclusions}

This study demonstrated the varying effectiveness of vegetation indices for remote detection of coffee rust signs and symptoms through correlation analyses of different indices. Vegetation indices obtained through relationships between bands in the Red-Edge and Near Infra-Red regions were more sensitive to changes caused by coffee leaf rust. Sentinel-2 orbital data transformed by calculating the IRECl vegetation index for August and September may be useful for indicating areas for coffee rust field sampling, and could be used to determine appropriate disease control according to variation in incidence rates. Future studies should examine the applicability of this vegetation index as a useful tool to aid in coffee plantation management.

Through this work it was also possible to characterize areas with different levels of disease incidence. The relationships between the monthly average spectral signature and levels of leaf rust incidence vary depending on the different regions of the electromagnetic spectrum. This may be due to the fact that the onset of the leaf senescence process reflectance peaks in most bands in the Red-Edge/ NIR region were higher in areas with higher incidence of coffee leaf rust.

Acknowledgements The authors would like to thank the Coordenação de Aperfeiçoamento de Pessoal de Nível Superior (CAPES) (88882.446773/2019-01), Conselho Nacional de Desenvolvimento Científico e Tecnológico (CNPq) for the productivity Scholarship (GRC), and Empresa de Pesquisa Agropecuária de Minas Gerais (EPAMIG), Fundação de Amparo à Pesquisa do Estado de Minas Gerais (FAPEMIG), Universidade Federal de Lavras (UFLA) and José Luis Tavares Cortez for supporting this study.

Authors' contribution MLJC, MCA and GRC conceived and designed this research. MLJC conducted experiments. MLJC analysed data. MLJC wrote the manuscript. MCA, GRC and EAP reviewed and contributed to the writing of the article. All authors read and approved the manuscript.

Funding This study was funded by the Coordination for the Improvement of Higher Education Personnel (CAPES) (Process Number: 88882.446773/2019-01), supported by the Minas Gerais Agricultural Research Corporation (EPAMIG) and the Federal University of Lavras.

Availability of data and materials Data are available.

Code availability Free software were used.

\section{Compliance with ethical standards}

Conflict of interest On behalf of all authors, the corresponding author states that there is no conflict of interest.

Consent to participate All authors declare that they are aware of their participation in the present work.

Consent for publication All authors declare that they are aware of the submission of this work. 


\section{References}

1. Alvares CA, Stape JL, Sentelhas PC, de Moraes G, Leonardo J, Sparovek G (2013) Köppen's climate classification map for Brazil. Meteorol Z 22:711-728. https://doi. org/10.1127/0941-2948/2013/0507

2. Alves MC, da Silva FM, Pozza EA, de Oliveira MS (2009) Modeling spatial variability and pattern of rust and brown eye spot in coffee agroecosystem. J Pest Sci 82:137-148. https://doi. org/10.1007/s10340-008-0232-y

3. Auernhammer $\mathrm{H}$ (2001) Precision farming-the environmental challenge. Comput Electron Agric 30:31-43. https://doi. org/10.1016/S0168-1699(00)00153-8

4. Avelino J, Willocquet L, Savary S (2004) Effects of crop management patterns on coffee rust epidemics. Plant Pathol 53:541547. https://doi.org/10.1111/j.1365-3059.2004.01067.x

5. Avelino J, Zelaya H, Merlo A, Pineda A, Ordóñez M, Savary S (2006) The intensity of a coffee rust epidemic is dependent on production situations. Ecol Model 197:431-447. https://doi. org/10.1016/j.ecolmodel.2006.03.013

6. Bock KR (1962) Dispersal of uredospores of Hemileia vastatrix under field conditions. Trans Br Mycol Soc 45:63-74. https://doi. org/10.1016/S0007-1536(62)80035-7

7. Boudrot A, Pico J, Merle I, Granados E, Vilchez S, Tixier P, VirginioFilho EM, Casanoves F, Tapia A, Allinne C, Rice RA, Avelino J (2016) Shade effects on the dispersal of airborne Hemileia vastatrix uredospores. Phytopathology 106:572-580. https://doi. org/10.1094/PHYTO-02-15-0058-R

8. Carvalho VL, Chalfoun SM, Castro HA, Carvalho VD (2001) Influence of different yield levels on coffee rust evolution and on phenolic compounds on leaves. Cienc Agrotecnol 25:49-54

9. Coops N, Stanford M, Old K, Dudzinski M, Culvenor D, Stone C (2003) Assessment of Dothistroma needle blight of Pinus radiata using airborne hyperspectral imagery. Phytopathology 93:1524-1532. https://doi.org/10.1094/PHYTO.2003.93.12.1524

10. Costa MJ, Zambolim L, Rodrigues FA (2006) Effect of levels of coffee berry removals on the incidence of rust and on the level of nutrients, carbohydrates and reductor sugar. Fitopatol Bras 31:564-571. https://doi.org/10.1590/S0100-415820060006000 05

11. Chavez PS Jr (1988) An improved dark-object subtraction technique for atmospheric scattering correction of multispectral data. Remote Sens Environ 24:459-479. https://doi. org/10.1016/0034-4257(88)90019-3

12. Chavez PS Jr (1989) Radiometric calibration of Landsat Thematic Mapper multispectral images. Photogramm Eng Remote Sens 55:1285-1294

13. Chemura A, Mutanga O, Dube T (2017) Separability of coffee leaf rust infection levels with machine learning methods at Sentinel-2 MSI spectral resolutions. Precis Agric 18:859-881. https:// doi.org/10.1007/s11119-016-9495-0

14. Chen JM (1996) Evaluation of vegetation indices and a modified simple ratio for boreal applications. Can J Remote Sens 22:229-242. https://doi.org/10.1080/07038992.1996.10855178

15. Custódio AAP, Pozza EA, Custódio AAP, Souza PE, Lima LA (2010) Effects of sun exposition on rust and cercospora leaf spot intensity on coffee plants. Coffee Sci 5:214-228

16. Custódio AAP, Pozza EA, Custódio AAP, Souza PE, Lima LA, Silva AM (2014) Effect of center-pivot irrigation in the rust and brown eye spot of coffee. Plant Dis 98:943-947. https://doi. org/10.1094/PDIS-07-13-0801-RE

17. Daughtry CST, Walthall CL, Kim MS, De Colstoun EB, McMurtrey JE III (2000) Estimating corn leaf chlorophyll concentration from leaf and canopy reflectance. Remote Sens Environ 74:229-239. https://doi.org/10.1016/S0034-4257(00)00113-9
18. Eitel JU, Vierling LA, Litvak ME, Long DS, Schulthess U, Ager AA, Krofcheck DJ, Stoscheck L (2011) Broadband, red-edge information from satellites improves early stress detection in a New Mexico conifer woodland. Remote Sens Environ 115:3640-3646. https://doi.org/10.1016/j.rse.2011.09.002

19. Empresa Brasileira de Pesquisa Agropecuária (1999) Controle da ferrugem o cafeeiro (Hemileia vastatrix) no estado de Rondônia. EMBRAPA. https://ainfo.cnptia.embrapa.br/digital/bitst ream/item/76700/1/FOL-7730-0001.pdf. Accessed 15 Oct 2019

20. European Space Agency (2015) Sentinel-2 user handbook. https ://sentinel.esa.int/documents/247904/685211/Sentinel-2_User_ Handbook. Accessed 17 Nov 2019

21. Ferreira LG, Ferreira NC, Ferreira ME (2008) Sensoriamento remoto da vegetação: evolução e estado-da-arte. Acta Sci Biol Sci 30:379-390. https://doi.org/10.4025/actascibiolsci.v30i4 .5868

22. Frampton WJ, Dash J, Watmough G, Milton EJ (2013) Evaluating the capabilities of Sentinel-2 for quantitative estimation of biophysical variables in vegetation. ISPRS J Photogramm 82:83-92. https://doi.org/10.1016/j.isprsjprs.2013.04.007

23. Gitelson A, Merzlyak MN (1994) Quantitative estimation of chlorophyll-a using reflectance spectra: experiments with autumn chestnut and maple leaves. J Photochem Photobiol B 22:247252. https://doi.org/10.1016/1011-1344(93)06963-4

24. Gitelson AA, Vina A, Ciganda V, Rundquist DC, Arkebauer TJ (2005) Remote estimation of canopy chlorophyll content in crops. Geophys Res Lett 32:1-4. https://doi.org/10.1029/2005G L022688

25. Guerfel M, Baccouri O, Boujnah D, Chaïbi W, Zarrouk M (2009) Impacts of water stress on gas exchange, water relations, chlorophyll content and leaf structure in the two main Tunisian olive (Olea europaea L.) cultivars. Sci Hortic 119:257-263. https://doi. org/10.1016/j.scienta.2008.08.006

26. Guimarães PTG, Garcia AWR, Alvarez VHA, Prezotti LC, Viana AS, Miguel AE, Malavolta E, Corrêa JB, Lopes AS, Nogueira FD, Monteiro AVC, Oliveira JA (1999) Cafeeiro. In: Ribeiro AC, Guimarães PTG, Alvarez VHA (eds) Recomendações para o uso de corretivos e fertilizantes em Minas Gerais - 5 a Aproximação. SBCS, Viçosa, pp 289-302

27. Gürtler S, Epiphanio JCN, Luiz AJB, Formaggio AR (2005) Electronic spreadsheet to acquire the reflectance from the TM and ETM + Landsat images. Revista Brasileira de Cartografia 57:162-167

28. Huete A, Didan K, Miura T, Rodriguez EP, Gao X, Ferreira LG (2002) Overview of the radiometric and biophysical performance of the MODIS vegetation indices. Remote Sens Environ 83:195-213. https://doi.org/10.1016/S0034-4257(02)00096-2

29. Hunt ER Jr, Rock BN, Nobel PS (1987) Measurement of leaf relative water content by infrared reflectance. Remote Sens Environ 22:429-435. https://doi.org/10.1016/0034-4257(87)90094-0

30. Instituto Nacional de Meteorologia. INMET. http://www.inmet .gov.br/portal/index.php?r=estacoes/estacoesConvencionais. Accessed 28 Oct 2019

31. Jensen JR (2011) Sensoriamento remoto do ambiente: uma perspectiva em recursos terrestres. Parêntese, São José dos Campos

32. Katsuhama N, Imai M, Naruse N, Takahashi Y (2018) Discrimination of areas infected with coffee leaf rust using a vegetation index. Remote Sens Lett 9:1186-1194. https://doi. org/10.1080/2150704X.2018.1519269

33. Knipling EB (1970) Physical and physiological basis for the reflectance of visible and near-infrared radiation from vegetation. Remote Sens Environ 1:155-159. https://doi.org/10.1016/ S0034-4257(70)80021-9

34. Kushalappa AC, Eskes AB (1989) Resistance. In: Kushalappa AC, Eskes $A B$ (eds) Coffee rust: epidemiology, resistance and management. CRC Press, Boca Raton, pp 171-292 
35. Liaghat S, Balasundram SK (2010) A review: the role of remote sensing in precision agriculture. Am J Agric Biol Sci 5:50-55. https://doi.org/10.3844/ajabssp.2010.50.55

36. Lima PC (1979) Método de amostragem para a avaliação do índice de infecção da ferrugem do cafeeiro (Hemileia vastatrix, Berk. and Br.). Dissertation, Escola Superior de Agricultura "Luiz de Queiroz"

37. López-Bravo DF, Virginio-Filho EM, Avelino J (2012) Shade is conducive to coffee rust as compared to full sun exposure under standardized fruit load conditions. Crop Prot 38:21-29. https:// doi.org/10.1016/j.cropro.2012.03.011

38. Nutman FJ, Roberts FM, Bock KR (1960) Method of uredospore dispersal of the coffee leaf-rust fungus, Hemileia vastatrix. Trans Br Mycol Soc 43:509-515. https://doi.org/10.1016/S0007 -1536(60)80033-2

39. Pozza EA, Carvalho VL, Chalfoun SM (2010) Sintomas de injúrias causadas por doenças do cafeeiro. In: Guimarães RJ, Mendes ANG, Baliza DP (eds) Semiologia do Cafeeiro. Editora UFLA, Lavras, pp 67-106

40. Pires MSO, Alves MC, Pozza EA (2020) Multispectral radiometric characterization of coffee rust epidemic in different irrigation management systems. Int J Appl Earth Obs 86:102016. https:// doi.org/10.1016/j.jag.2019.102016

41. Rondeaux G, Steven M, Baret F (1996) Optimization of soiladjusted vegetation indices. Remote Sens Environ 55:95-107. https://doi.org/10.1016/0034-4257(95)00186-7

42. Rouse Jr J, Haas RH, Schell, JA, Deering DW (1974) Monitoring vegetation systems in the Great Plains with ERTS. Goddard Space Flight Center 3d ERTS-1 symposium, vol 1, pp 309-317

43. Silva MG, Pozza EA, Vasco GB, Freitas AS, Chaves E, Paula PVAA Dornelas GA, Alves MC, Silva MLO, Pozza AAA (2019) Geostatistical analysis of coffee leaf rust in irrigated crops and its relation to plant nutrition and soil fertility. Phytoparasitica 47:117-134. https://doi.org/10.1007/s12600-019-00714-5

44. United States Geological Survey. USGS. https://earthexplorer. usgs.gov/. Accessed 23 April 2019

45. Viola MR, de Mello CR, Pinto DB, de Mello JM, Ávila LF (2010) Spatial interpolation methods for mapping of rainfall. Rev Bras Eng Agríc Ambient 14:970-978. https://doi.org/10.1590/S1415 $-43662010000900009$

46. Wilson EH, Sader SA (2002) Detection of forest harvest type using multiple dates of Landsat TM imagery. Remote Sens Environ 80:385-396. https://doi.org/10.1016/S0034-4257(01)00318 $-2$

47. Wu C, Niu Z, Tang Q, Huang W (2008) Estimating chlorophyll content from hyperspectral vegetation indices: modeling and validation. Agric For Meteorol 148:1230-1241. https://doi. org/10.1016/j.agrformet.2008.03.005

48. Zambolim L, Silva-Acuña R, Do Vale FXR, Chaves GM (1992) Influência da produção do cafeeiro sobre o desenvolvimento da ferrugem (Hemileia vastatrix). Fitopatol Bras 17:32-35

49. Zambolim L (2016) Current status and management of coffee leaf rust in Brazil. Trop Plant Pathol 41:1-8. https://doi. org/10.1007/s40858-016-0065-9

50. Zheng Q, Huang W, Cui X, Shi Y, Liu L (2018) New spectral index for detecting wheat yellow rust using Sentinel-2 multispectral imagery. Sensors 18:868-887. https://doi.org/10.3390/s1803 0868

Publisher's Note Springer Nature remains neutral with regard to jurisdictional claims in published maps and institutional affiliations. 